\title{
THE EFFECT OF POTATO RUGOSE ON THE YIELD OF SOME POTATO VARIETIES
}

\author{
Onni Pohjakallio, Laura Karhuvaara and Simo Antila \\ Department of Plant Pathology, University of Helsinki
}

Received January 31, 1961

In field experiments, the tuber yield of potato rugose diseased plants of $\mathrm{F}_{1}$ clones descended from the species hybridization Solanum demissum $x$ S. tuberosum (Rosafolia) appeared to amount on an average to about $35 \%$ of that of the healthy plants (6). Howerer, it seemed that the strength of the disease manifested itself differently in the clones infected during the different years. Variations which had arisen from bud mutations were observed in this potato material, and thus no answer had been given to the question of whether the variation in the strength of the disease depended on the heterogeneity of the potato material or on that of the virus infecting it. In the following, the study of the effect of the potato rugose on the yield of the potato is based on more uniform potato material. Most of the investigations were made with the variety Harbinger; some experiments were also carried out with the varieties Aquila and King George V.

In the field experiments proper, which began in 1953, the tubers were set at distances of 1.2 metres (Fig. 1) apart, and the tuber yield of each plant was put into a separate paper bag, in which it was preserved over the winter. Consequently, the tubers of the different potato plants were not mixed together, and furthermore the potato plants did not touch each other either in the field or during storage. Ac-

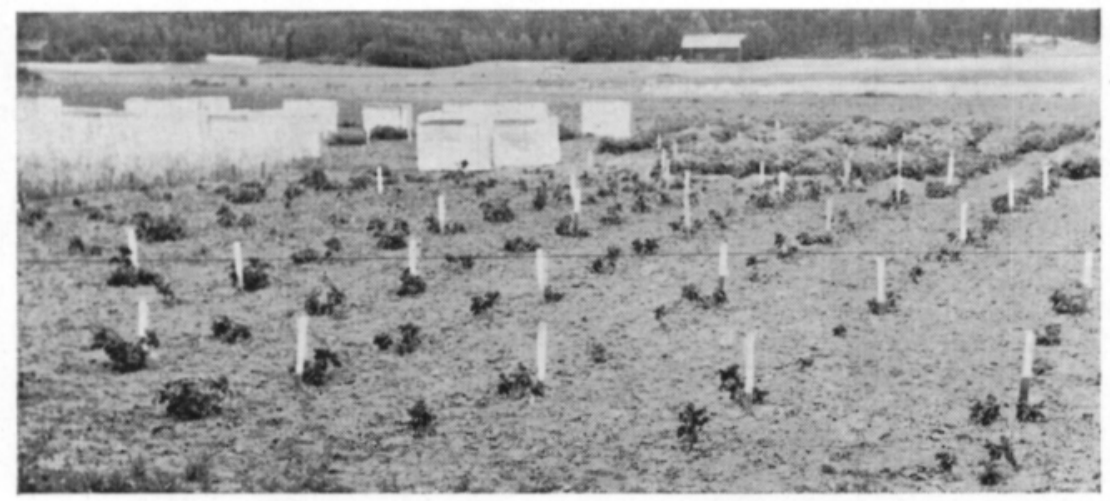

Fig. 1. Field experiments with the virus-diseased Harbinger potato plants. 
cordingly, only vectors could have been the reason for the transmission of the infection; there were plenty of aphids on the potato plants in summertime. In some field experiments, in which was studied only the appearance of the virus disease in different potato varieties (Table 7 ), the potato plants were planted at distances of $0.30 \times 0.65$ metres.

\section{Experiments with Harbinger variety}

For the first field experiments carried out in 1946, Tammisto Plant Breeding Station provided tubers of the Harbinger potato variety. At that time its tuber yield appeared to be relatively high. In the following year (1947) the productiveness of the variety Harbinger in comparison with that of the other potato varieties investigated was somewhat lower. The first observation on the appearance of the virus disease were made in 1948 . The diseased potato plants then amounted to $53 \%$ of the whole; in the following year (1949) the corresponding figure was $89 \%$.

The plants vegetatively descending from potato plants which had shown themselves to be healthy in the preceding summer were studied from the year 1952; the corresponding rates of the diseased plants from 1952 to 1957 were as follows: $66 \%, 46 \%, 65 \%, 89 \%, 94 \%$, and $100 \%$. New, healthy setting tubers of the variety Harbinger were obtained from Inari in 1956. Some of the plants descended from these tubers showed symptoms of the virus disease as early as in 1957. The proportions of diseased plants vegetatively descended from potato plants which had seemed to be healthy in the preceding summer were in 1958 and 1959 correspondingly $64 \%$ and $100 \%$. In 1960, again, tubers of healthy Harbinger potato variety were obtained from Inari. None of the plants grown from these tubers showed symptoms of the virus disease in the summer of 1960 .

These facts show that the virus disease appeared increasingly in the subsequent vegetative progenies of the potato plants which seemed to be healthy. Moreover, the average tuber yields of the Harbinger potato plants without symptoms were from year to year still lower per plant, or in $19531380 \mathrm{~g}$., in $19541280 \mathrm{~g}$., in 1955 $820 \mathrm{~g}$., and $1956720 \mathrm{~g}$. The corresponding yields of the variety Harbinger, the setting tubers of which were obtained from Inari in 1956, were in $19571100 \mathrm{~g}$., and in $1958680 \mathrm{~g}$. Further, in many cases, the symptoms of the virus disease appeared in the progenies of the seemingly healthy plants after their sprouting, and soon enough to convince one that the infection must already have taken place in the preceding summer (Table 1). Consequently, some of the healthy looking plants had also been infected by the virus. In 1954 and 1960 , the plants were infected with potato late blight very early, and consequently in most cases the primary symptoms of the virus disease were perhaps not observed. On the other hand, the virus infection may often take place so late in the autumn that the visible symptoms do not become apparent before the lifting of the yield.

In the summer of 1959, the temperature was higher and the precipitation lower than normal. There was practically no late blight to observe. On the contrary, large numbers of aphids appeared on the potato plants. The primary symptoms of the virus disease manifested themselves in the variety Harbinger from 24th to 27th 
Table 1. Dates of the appearance of virus disease in Harbinger potato plants descended from plants in which no symptoms had been observed in the preceding summer.

\begin{tabular}{|c|c|c|c|c|}
\hline Year & $\begin{array}{l}\text { Date of } \\
\text { setting }\end{array}$ & $\begin{array}{l}\text { Date of } \\
\text { sprouting }\end{array}$ & $\begin{array}{l}\text { Date of } \\
\text { lifting }\end{array}$ & $\begin{array}{c}\text { The disease became } \\
\text { visible }\end{array}$ \\
\hline 1953 & $27 / 5$ & $12-19 / 6$ & $12 / 9$ & $22 / 6-21 / 7$ \\
\hline 1954 & $28 / 5$ & $10-19 / 6$ & $8 / 9$ & $26 / 6-3 / 8$ \\
\hline 1955 & $4 / 6$ & $24 / 6-1 / 7$ & $24 / 9$ & $27 / 6-3 / 7$ \\
\hline 1956 & $2 / 6$ & $15 / 6-3 / 7$ & $4 / 9$ & $\left.25 / 6-25 / 7^{1}\right)$ \\
\hline 1957 & $24 / 5$ & $11-24 / 6$ & $11-12 / 9$ & $24 / 6-19 / 8$ \\
\hline 1958 & $5 / 6$ & $18-28 / 6$ & $11 / 9$ & $28 / 6-2 / 7$ \\
\hline 1959 & $15 / 5$ & $1-8 / 6$ & $17 / 9$ & $\left.6 / 7-27 / 7^{2}\right)$ \\
\hline
\end{tabular}

$\left.{ }^{1}\right)$ One potato plant showed virus symptoms on 27th July, the others at the turn of June and July.

$\left.{ }^{2}\right)$ One potato plant showed virus symptoms on 6 th July, one on 16 th July, the others (18 plants) on 24 th to 27 th July.

July with unusual severity; the uppermost leaves of the plants died and turned brown as if damaged by frost (Fig. 2). Despite this, the amount of the tuber yield of these plants was relatively high (Table 4). Moreover, in other cases also the effect of the primary virus infection on the tuber yield was not very injurious (Table 2 ). On the contrary, the tuber yields of the vegetative progenies of the virus-infec-

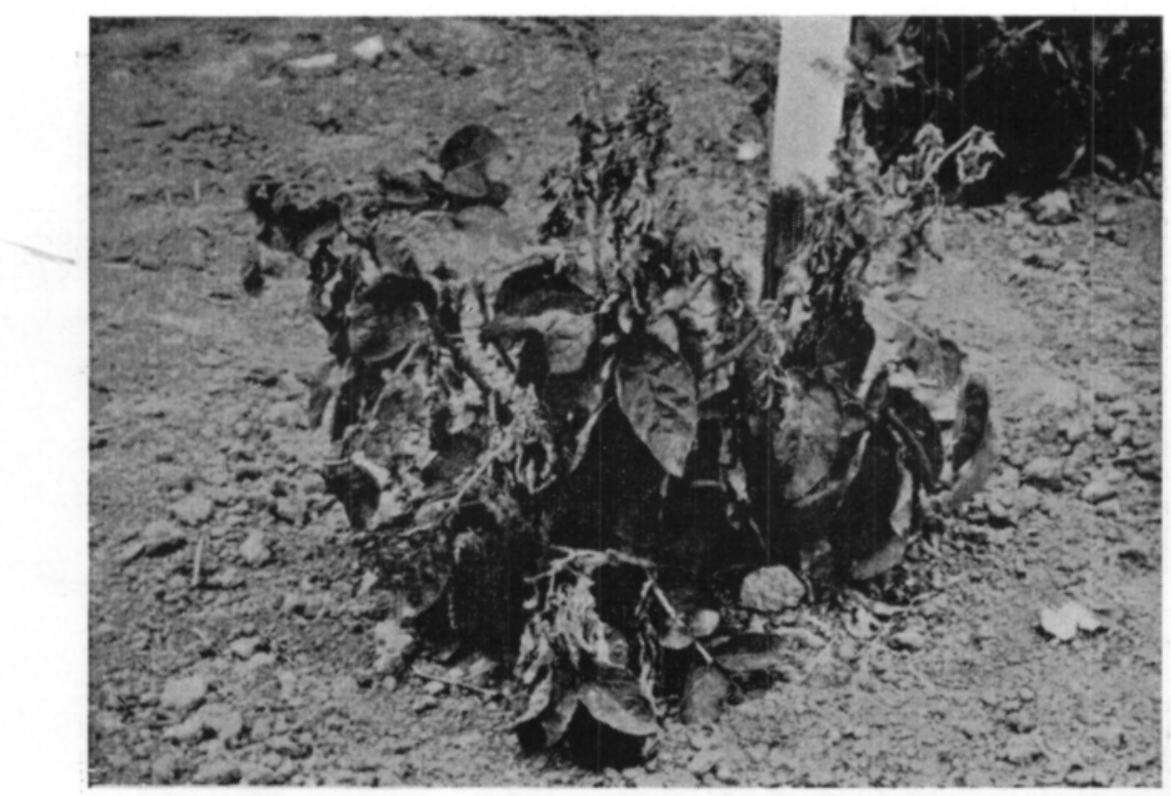

Fig. 2. In 1959, the primary symptoms of the virus disease in the potato variety Harbinger occurred with exceptional severity. 
ted potato plants appeared to be low (Tables 3 to 4 ). Subsequently, the degeneration did not progress from one vegetative generation of the diseased plants to the next.

Table 2. The effect of the date of appearance of the virus disease on the tuber yield of Harbinger potato in 1957 (the slight type of the virus disease).

\begin{tabular}{lcrc}
\hline $\begin{array}{c}\text { The disease } \\
\text { became visible }\end{array}$ & No. of plants & $\begin{array}{c}\text { Tuber yield per } \\
\text { plant }(\mathrm{g})\end{array}$ \\
\hline Before 7th July & 10 & 227 \\
After 7th July & 13 & 494 \\
Healthy plants & 2 & 1098 &
\end{tabular}

The symptoms of the virus disease varied in the different potato plants. Each of the types of symptom manifested itself as unvarying from one vegetative generation of the potato to the next. Part of the vegetative progenies of one and the same healthy potato plant were affected by one, and part by another type of the virus disease. The severe t y p e of the disease caused death of the lowermost leaves of the haulms, and green leaves were left only at the tops of the shoots (Fig. 3); the leaflets were wrinkled, and the whole of the plant withered early. The slight ty pe of the disease also caused wrinkled leaflets, but the lowermost leaves of the plant did not die (Fig. 4). There was a distinct difference between the effect of these types of the disease on the amount of the tuber yield (Tables 3 and 4) as well as on that

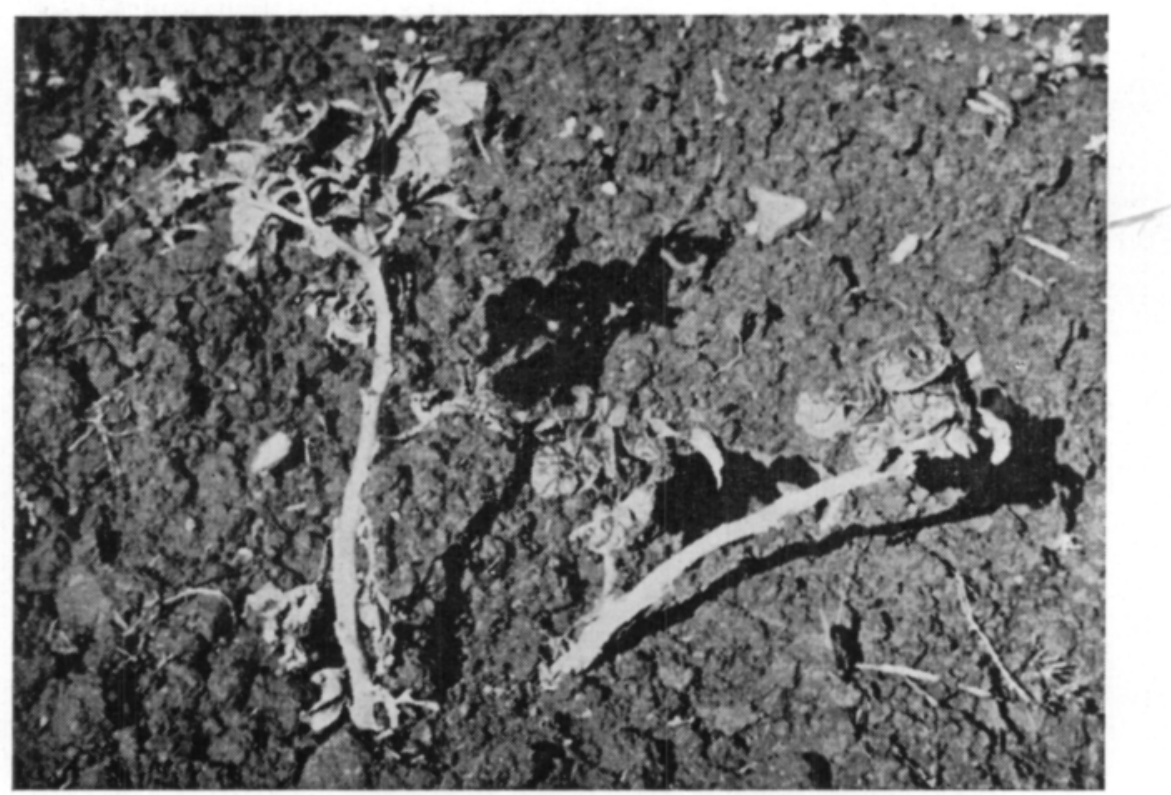

Fig. 3. Secondary symptoms of the severe type of the virus disease in the variety Harbinger. 
of the top yield (Table 5) of the potato. Moreover, there were intermediate forms of these two extreme types of the disease to be observed. In field experiments carried out in 1957 the average tuber yields per plant of the variety Harbinger affected by the different types of the virus disease were as follows: the slight type $281 \mathrm{~g}$. (77 plants), the intermediate types $169 \mathrm{~g}$. (32 plants), and the severe type $73 \mathrm{~g}$. ( 37 plants). The disease had appeared in 1956 or earlier in the vegetative parents of all these plants. In the years 1957 to 1960 , the rate of the tuber yield of the slightly diseased plants related to that of those with no symptoms averaged $27 \%$ (Table 3 ); that of the severely diseased plants was about $5 \%$ (Table 4 ). The effect of the inter-

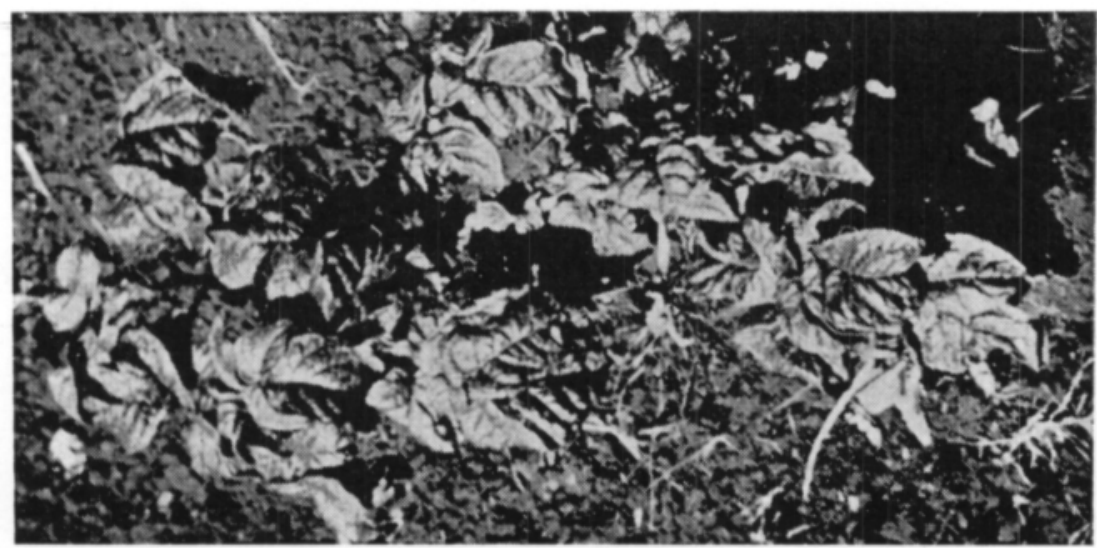

Fig. 4. Secondary symptoms of the slight type of virus disease in the variety Harbinger.

Table 3. The effect of the slight type of the virus disease on the tuber yield of the Harbinger potato variety. (In 1959 and 1960 no new plants showed any symptoms of this type of virus disease).

\begin{tabular}{|c|c|c|c|c|c|c|c|c|c|c|c|c|}
\hline \multirow{3}{*}{$\begin{array}{l}\text { The } \\
\text { disease } \\
\text { became } \\
\text { visible } \\
\text { (year) }\end{array}$} & \multicolumn{3}{|c|}{$\begin{array}{l}\text { Results } \\
\text { in } 1957\end{array}$} & \multicolumn{3}{|c|}{$\begin{array}{l}\text { Results } \\
\text { in } 1958\end{array}$} & \multicolumn{3}{|c|}{$\begin{array}{l}\text { Results } \\
\text { in } 1959\end{array}$} & \multicolumn{3}{|c|}{$\begin{array}{l}\text { Results } \\
\text { in } 1960\end{array}$} \\
\hline & \multirow[b]{2}{*}{$\begin{array}{l}\text { No. } \\
\text { of } \\
\text { plants } \\
\text { stud- } \\
\text { ied }\end{array}$} & \multicolumn{2}{|c|}{ Yield/plant } & \multirow[b]{2}{*}{$\begin{array}{l}\text { No. } \\
\text { fo } \\
\text { plants } \\
\text { stud- } \\
\text { ied }\end{array}$} & \multicolumn{2}{|c|}{ Yield/plant } & \multirow[b]{2}{*}{$\begin{array}{l}\text { No. } \\
\text { of } \\
\text { plants } \\
\text { stud- } \\
\text { ied }\end{array}$} & \multicolumn{2}{|c|}{ Yield/plant } & \multirow[b]{2}{*}{$\begin{array}{c}\text { No. } \\
\text { of } \\
\text { plants } \\
\text { stud- } \\
\text { ied }\end{array}$} & \multicolumn{2}{|c|}{ Yield/plant } \\
\hline & & $\begin{array}{c}\text { No. } \\
\text { of } \\
\text { tub- } \\
\text { ers }\end{array}$ & g. & & $\begin{array}{c}\text { No. } \\
\text { of } \\
\text { tub- } \\
\text { ers }\end{array}$ & g. & & $\begin{array}{c}\text { No. } \\
\text { of } \\
\text { tub- } \\
\text { ers }\end{array}$ & g. & & $\begin{array}{l}\text { No. } \\
\text { of } \\
\text { tub- } \\
\text { ers }\end{array}$ & g. \\
\hline 1953 & 24 & 10 & 379 & 25 & 6 & 240 & 10 & 6 & 391 & 15 & 9 & 447 \\
\hline 1954 & 22 & 8 & 274 & 18 & 6 & 218 & 8 & 4 & 205 & 15 & 7 & 266 \\
\hline 1955 & 11 & 9 & 255 & 24 & 5 & 202 & 10 & 5 & 310 & 15 & 8 & 312 \\
\hline 1956 & 20 & 6 & 184 & 10 & 5 & 215 & 10 & 5 & 350 & 15 & 8 & 286 \\
\hline 1957 & 23 & 13 & 377 & 17 & 5 & 163 & 10 & 4 & 194 & 15 & 4 & 129 \\
\hline 1958 & & & & 16 & 6 & 171 & 5 & 3 & 140 & 15 & 7 & 169 \\
\hline $\begin{array}{l}\text { Without } \\
\text { symptoms }\end{array}$ & 2 & 30 & 1098 & 12 & 16 & 521 & $-1)$ & $-1)$ & $-1)$ & 19 & 20 & 1623 \\
\hline
\end{tabular}

1) All the plants were virus diseased. 
Table 4. The effect of the severe type of the virus disease on the tuber yield of the Harbinger potato variety. (In 1960 no new plants showed any symptoms of this virus disease).

\begin{tabular}{|c|c|c|c|c|c|c|c|c|c|c|c|c|}
\hline \multirow{3}{*}{$\begin{array}{l}\text { The } \\
\text { disease } \\
\text { became } \\
\text { visible } \\
\text { (year) }\end{array}$} & \multicolumn{3}{|c|}{$\begin{array}{l}\text { Results } \\
\text { in } 1957\end{array}$} & \multicolumn{3}{|c|}{$\begin{array}{l}\text { Results } \\
\text { in } 1958\end{array}$} & \multicolumn{3}{|c|}{$\begin{array}{l}\text { Results } \\
\text { in } 1959\end{array}$} & \multicolumn{3}{|c|}{$\begin{array}{l}\text { Results } \\
\text { in } 1960\end{array}$} \\
\hline & \multirow{2}{*}{$\begin{array}{c}\text { No. } \\
\text { of } \\
\text { plants } \\
\text { stud- } \\
\text { ied }\end{array}$} & \multicolumn{2}{|c|}{ Yield/plant } & \multirow{2}{*}{$\begin{array}{c}\text { No. } \\
\text { of } \\
\text { plants } \\
\text { stud- } \\
\text { ied }\end{array}$} & \multicolumn{2}{|c|}{ Yield/plant } & \multirow{2}{*}{$\begin{array}{c}\text { No. } \\
\text { of } \\
\text { plants } \\
\text { stud- } \\
\text { ied }\end{array}$} & \multicolumn{2}{|c|}{ Yield/plant } & \multirow{2}{*}{$\begin{array}{c}\text { No. } \\
\text { of } \\
\text { plants } \\
\text { stud- } \\
\text { ied }\end{array}$} & \multicolumn{2}{|c|}{ Yield/plant } \\
\hline & & $\begin{array}{c}\text { No.of } \\
\text { tub- } \\
\text { ers }\end{array}$ & g. & & $\begin{array}{c}\text { No.of } \\
\text { tub- } \\
\text { ers }\end{array}$ & g. & & $\begin{array}{c}\text { No.of } \\
\text { tub- } \\
\text { ers }\end{array}$ & g. & & $\begin{array}{l}\text { No.of } \\
\text { tub- } \\
\text { ers }\end{array}$ & g. \\
\hline 1953 & 10 & 4 & 117 & 10 & 3 & 64 & 6 & 2 & 130 & 14 & 6 & 147 \\
\hline 1954 & 4 & 3 & 85 & 9 & 3 & 29 & 10 & 3 & 26 & 15 & 3 & 52 \\
\hline 1955 & 14 & 3 & 58 & 11 & 2 & 18 & 5 & 2 & 34 & 11 & 3 & 26 \\
\hline 1956 & 9 & 2 & 43 & 23 & 3 & 30 & 10 & 1 & 13 & 12 & 2 & 12 \\
\hline 1957 & 3 & 9 & 263 & 10 & 3 & 24 & 8 & 2 & 19 & 14 & 2 & 5 \\
\hline 1958 & & & & 17 & 4 & 37 & 10 & 3 & 23 & 12 & 1 & 4 \\
\hline 1959 & & & & & & & 15 & 27 & 838 & 15 & 5 & 33 \\
\hline $\begin{array}{l}\text { Without } \\
\text { symptoms }\end{array}$ & 2 & 30 & 1098 & 12 & 16 & 521 & $-1)$ & $\left.-{ }^{1}\right)$ & $\left.-{ }^{1}\right)$ & 19 & 20 & 1623 \\
\hline
\end{tabular}

1) All the plants were virus diseased.

mediate forms of the virus disease on the tuber yield of the potato is not referred to in the tables attached. Further, the two extreme types of the virus disease did not appear to be quite uniform. For example, the tuber yields of the plants vegetatively descended from the Harbinger potato plants, which were in 1953 noted as being affected by the severe type of the virus disease, continued relatively high (Table 4). Correspondingly, the top yield of these plants appeared to be higher than that of the others (Table 5), even if the dying of their lowermost leaves was also apparent. On the other hand, the vegetative progenies of the plants which had been infected in 1956 to 1958 were very small-sized and their tuber yields very low (Table 4). The slight type of the virus disease seemed to be more uniform (Table 3).

Table 5. The effect of the virus disease on the top yield of the Harbinger potato variety in 1956.

\begin{tabular}{ccc}
\hline $\begin{array}{c}\text { The disease } \\
\text { became } \\
\text { visible } \\
\text { (year) }\end{array}$ & $\begin{array}{c}\text { Top yield on 3rd Sept. per plant } \\
\text { of virus disease }\end{array}$ & $\begin{array}{c}\text { Severe type } \\
\text { of virus disease }\end{array}$ \\
\hline 1953 & $36 \pm 2.1$ & $20 \pm 2.4$ \\
1954 & $38 \pm 5.4$ & $19 \pm 3.5$ \\
1955 & $56 \pm 4.3$ & $15 \pm 4.0$ \\
1956 & $58 \pm 4.6$ & $14 \pm 4.0$ \\
Without symptoms & $\left.155^{1}\right)$ & $\left.155^{1}\right)$ \\
1956 & &
\end{tabular}

1) Only 2 plants. 
According to serological investigations carried out in 1957 (cf. 6), virus S was present in most of the Harbinger potato plants studied. Virus S was present in plants with the severe types of symptom as well as in those with slighter symptoms, However, the sap of some of the diseased plants did not react positively with the antiserum against potato virus $\mathrm{S}$, and, on the other hand, the virus also appeared to be present in 16 seemingly healthy plants descended from the tubers obtained from Inari in 1956. Consequently, virus S was hardly the cause of the virus disease studied.

According to the findings of corresponding investigations, potato virus $\mathrm{X}$ was present in none of the 14 seemingly healthy, nor in the 52 diseased Harbinger potato plants investigated. By contrast, an antiserum against potato virus $\mathrm{Y}$ caused agglutination in the sap of most of the Harbinger potato plants. As in many cases the normal serum used also reacted positively with the sap of these plants, the result cannot be considered conclusive, however. Nevertheless, the secondary symptoms of the severe type of the disease were typical of the potato rugose caused by potato

Table 6. The effect of the virus disease on the tuber yield of the variety Aquila.

\begin{tabular}{|c|c|c|c|c|c|c|c|c|c|}
\hline \multirow{3}{*}{$\begin{array}{l}\text { The } \\
\text { diease } \\
\text { became } \\
\text { visible } \\
\text { (year) }\end{array}$} & \multicolumn{3}{|c|}{$\begin{array}{l}\text { Results } \\
\text { in } 1958\end{array}$} & \multicolumn{3}{|c|}{$\begin{array}{l}\text { Results } \\
\text { in } 1959\end{array}$} & \multicolumn{3}{|c|}{$\begin{array}{l}\text { Results } \\
\text { in } 1960\end{array}$} \\
\hline & \multirow[b]{2}{*}{$\begin{array}{l}\text { No.of } \\
\text { plants } \\
\text { studied }\end{array}$} & \multicolumn{2}{|c|}{ Yield/plant } & \multirow[b]{2}{*}{$\begin{array}{l}\text { No.of } \\
\text { plants } \\
\text { studied }\end{array}$} & \multicolumn{2}{|c|}{ Yield/plant } & \multirow[b]{2}{*}{$\begin{array}{l}\text { No.of } \\
\text { plants } \\
\text { studied }\end{array}$} & \multicolumn{2}{|c|}{ Yield/plant } \\
\hline & & $\begin{array}{l}\text { No. of } \\
\text { tubers }\end{array}$ & g. & & $\begin{array}{l}\text { No.of } \\
\text { tubers }\end{array}$ & g. & & $\begin{array}{l}\text { No.of } \\
\text { tubers }\end{array}$ & g. \\
\hline 1956 & 14 & 1 & 18 & 14 & 2 & 24 & 14 & 3 & 25 \\
\hline 1957 & 5 & 11 & 431 & 20 & 5 & 122 & 15 & 4 & 44 \\
\hline 1958 & 2 & 19 & 863 & $-1)$ & $-1)$ & $-1)$ & $-1)$ & $-1)$ & $\left.-{ }^{1}\right)$ \\
\hline 1959 & & & & 17 & 25 & 2412 & 15 & 7 & 136 \\
\hline 1960 & & & & & & & 19 & 3 & 79 \\
\hline $\begin{array}{l}\text { Without } \\
\text { symptoms }\end{array}$ & 18 & 17 & 1192 & 2 & 28 & 2186 & 1 & 22 & 2622 \\
\hline
\end{tabular}

1) No new plants diseased.

virus Y. The plants remained small, and their haulms were limp. The leaves became wrinkled, their structure was fragile, and at the beginning they were mottled in colour. There were light-brown-coloured, necrotic spots on the leaflets, and the leaves died, starting from the base of the haulms, until living leaves were left only at the tops of the shoots (Fig. 3). On the under side of the leaflets, the necrotic streaks which are typical of the potato rugose in many potato varieties during the primary phase of the infection, did not, however, occur in the variety Harbinger. Instead, there were to be observed on the leaflets shapeless, initially yellow, and later brown-coloured spots. For the slight and the severe types of the disease, the primary symptoms were almost alike. Instead, the secondary symptoms of the former type of the disease occurred to a distinctly slighter extent, and the lowest leaves 
of the shoots did not die. Neither of these two extreme types of the disease, nor any of the intermediate types changed in a single potato plant or its vegetative progeny into any another type of the disease.

Almost all the vegetative progenies of the infected potato plants showed symptoms of the virus disease. From the tubers of only one plant did both diseased and healthy potato plants arise.

\section{Experiments with A quila variety}

Healthy and virus-diseased plants both grew from the tubers of only one Aquila potato plant. In this plant, the primary symptoms did not appear until the 11th September (in 1957). In all other cases studied, each of the vegetative progenies of the virus-infected plants was diseased.

Also in the variety Aquila, the symptoms of the virus disease did not in some instances become evident before the summer following the infection. For example,

Table 7. Occurrence of virus disease in varieties Harbinger and Aquila in a field experiment, in which virus-infected Harbinger-potatoes were set between the experimental plots.

\begin{tabular}{cccc}
\hline Variety & \multicolumn{3}{c}{ No. of diseased plants } \\
\cline { 3 - 4 } & $\begin{array}{c}\text { In 1958 } \\
(20 \text { plants })\end{array}$ & $\begin{array}{c}\text { In 1959 } \\
(20 \text { plants })\end{array}$ & $\begin{array}{c}\text { In 1960 } \\
(30 \text { plants })\end{array}$ \\
\hline Harbinger & 0 & 11 & 30 \\
Aquila & 0 & 1 & 4
\end{tabular}

in 1960 the symptoms of the virus disease appeared in the plants very soon after their sprouting (Table 8). Variety Aquila proved to be extremely resistant to potato blight. Consequently, this disease did not disturb the observation of the primary symptoms of virus disease in Aquila potato plants. When the primary symptoms did not appear before late in the autumn, the effect of the virus disease on the amount of the tuber yield of the potato plants was exceedingly minute (Table 9). On the other hand, the secondary phase of the virus-disease caused severe degeneration of

Table 8. Dates of appearance of the symptoms of virus disease in the Aquila-potato plants descended from plants in which no symptoms had been observed in the preceding summer.

\begin{tabular}{crrrr}
\hline Year & $\begin{array}{l}\text { Date of } \\
\text { setting }\end{array}$ & $\begin{array}{c}\text { Date of } \\
\text { sprouting }\end{array}$ & $\begin{array}{l}\text { Date of } \\
\text { lifting }\end{array}$ & $\begin{array}{c}\text { The disease } \\
\text { became visible }\end{array}$ \\
\hline 1957 & $24 / 5$ & $12-25 / 6$ & $12 / 9$ & $9 / 8-11 / 9$ \\
1958 & $5 / 6$ & $18-28 / 6$ & $12 / 9$ & $2 / 9-5 / 9$ \\
1959 & $15 / 5$ & $2-5 / 6$ & $19 / 9$ & $31 / 7-4 / 9$ \\
1960 & $30 / 5$ & $13-30 / 6$ & $15 / 9$ & $30 / 6-14 / 7$
\end{tabular}


Table 9. The effect of the date of appearance of the virus disease on the amount of tuber yield of Aquilapotato.

\begin{tabular}{|c|c|c|c|c|c|c|}
\hline \multirow[t]{3}{*}{. Year } & \multicolumn{6}{|c|}{ The disease became visible } \\
\hline & \multicolumn{2}{|c|}{ Before 7th July } & \multicolumn{2}{|c|}{ After 7th July } & \multicolumn{2}{|c|}{ Healthy plants } \\
\hline & $\begin{array}{l}\text { No.of } \\
\text { plants } \\
\text { studied }\end{array}$ & $\begin{array}{c}\text { Tubers/plant } \\
\text { g. }\end{array}$ & $\begin{array}{l}\text { No.of } \\
\text { plants } \\
\text { studied }\end{array}$ & $\begin{array}{c}\text { Tubers/plant } \\
\text { g. }\end{array}$ & $\begin{array}{l}\text { No.of } \\
\text { plants } \\
\text { studied }\end{array}$ & $\begin{array}{c}\text { Tubers/plant } \\
\text { g. }\end{array}$ \\
\hline 1957 & - & - & 14 & 1382 & 20 & 1864 \\
\hline 1958 & - & - & 2 & 863 & 18 & 1192 \\
\hline 1959 & - & - & 17 & 2412 & 2 & 2186 \\
\hline 1960 & 6 & 6 & 13 & 115 & 1 & 2622 \\
\hline
\end{tabular}

the plants. The rate of the tuber yield of the virus-diseased plants in comparison with that of the healthy ones appeared to average only $6 \%$. In the variety Aquila, only the severe type of the disease was observed. It seems, however, that also this potato variety was affected by virus infections of varying severity in different years (Table 6). According to the results of a special field experiment (Table 7), virus infections occurred much more frequently in Harbinger than in the Aquila potato variety.

Serological investigations showed that potato virus $\mathrm{X}$ was not present in the diseased Aquila potato plants. Virus S was found in only some of the plants. An a g g l u t in a tion test with antiserum against virus $\mathrm{Y}$ gave a positive result in the sap of the majority of the plants, but the normal serum used also caused the same reaction. However, dark brown, necrotic streaks occurring on the under side of the leaflets, characteristic of the potato rugose caused by potato virus $\mathrm{Y}$, were also the primary symptoms of the virus disease appearing in the variety Aquila. The secondary symptoms were almost the same as those characteristic of the severe type of the disease occurring in the variety Harbinger. Generally, the variety Aquila was infected only when growing in the immediate vicinity of virus-diseased Harbinger potato plants.

\section{Experiments with King George V variety}

In the potato variety King George $\mathrm{V}$, the virus disease manifested itself in a way similar to its occurrence in the variety Aquila. The tuber yield of the diseased plants appeared to be very low (Table 10).

\section{Discussion}

The variety Aquila did not become virus-infected as frequently as the variety Harbinger (Table 7). The variety Harbinger has generally appeared to be particularly susceptible to the virus disease $(2,3$, and 4$)$. However, when the plants were virus-infected, the severity of the disease showed almost exact correspondence in the three potato varieties studied (Tables 4,6 , and 10). 
The rate of the tuber yield of the diseased Aquila plants, in comparison with that of the healthy ones, averaged $6 \%$ (Table 6 ). The corresponding figure for Harbinger was $5 \%$ (Table 4). The productivity of the diseased plants of the variety King George V changed to a corresponding level (Table 10). In the experiments carried out by BRUMMER $(2,3)$ with the variety King George V, the corresponding figure was nearly the same, or $9 \%$, but in experiments with the variety Harbinger

Table 10. The effect of the virus disease on the tuber yield of the variety King George V. ${ }^{1}$ )

\begin{tabular}{|c|c|c|c|c|c|c|}
\hline \multirow{3}{*}{$\begin{array}{l}\text { The disease } \\
\text { became } \\
\text { visible } \\
\text { (year) }\end{array}$} & \multicolumn{3}{|c|}{$\begin{array}{l}\text { Results } \\
\text { in } 1958\end{array}$} & \multicolumn{3}{|c|}{$\begin{array}{l}\text { Results } \\
\text { in } 1959\end{array}$} \\
\hline & \multirow{2}{*}{$\begin{array}{l}\text { No.of } \\
\text { plants } \\
\text { studied }\end{array}$} & \multicolumn{2}{|c|}{ Yield/plant } & \multirow{2}{*}{$\begin{array}{l}\text { No.of } \\
\text { plants } \\
\text { studied }\end{array}$} & \multicolumn{2}{|c|}{ Yield/plant } \\
\hline & & $\begin{array}{l}\text { No.of } \\
\text { tubers }\end{array}$ & g. & & $\begin{array}{l}\text { No.of } \\
\text { tubers }\end{array}$ & g. \\
\hline 1956 & 4 & 2 & 18 & 4 & 1 & 11 \\
\hline 1957 & 9 & 5 & 48 & 9 & 3 & 17 \\
\hline 1958 & 4 & 4 & 31 & 7 & 1 & 4 \\
\hline 1959 & & & & 8 & 17 & 2005 \\
\hline $\begin{array}{l}\text { Without } \\
\text { symptoms }\end{array}$ & 1 & 15 & 787 & $\left.-{ }^{2}\right)$ & $\left.-{ }^{2}\right)$ & $\left.-{ }^{2}\right)$ \\
\hline
\end{tabular}

$\left.{ }^{1}\right)$ The tuber yield in 1960 of the vegetative progenies of plants (13) which had been infected in 1956 was $22 \mathrm{~g}$ ( 3 tubers) per plant.

$\left.{ }^{2}\right)$ No healthy plants.

it was noticeably higher, or $32 \%$. In our investigations, apart from observation of the severe type of the disease (Table 4), attention was directed to a slight form (Table 3 ), and to intermediate ones. Their nature was characteri ed by the tuber yields (Tables 3 and 4), and the top yields (Table 5), as well as by the character of the secondary symptoms (Figs. 3 and 4 ).

It is known that in some potato varieties a simultaneous infection by viruses $\mathrm{Y}$ and $\mathrm{X}$ causes symptoms which resemble those characteristic of the slight type of the virus disease occurring in the potato variety Harbinger (cf. 5). In the case examined in this paper, however, a simultaneous infection was hardly possible, because the different types of the disease, without exception, retained their special features from one vegetative generation of the potato to the next. According to the results of the serological investigations, virus $\mathrm{X}$ was not present in the potato variety Harbinger; the varieties King George $\mathrm{V}$ and Aquila also were not infected by potato virus X. Further, in some cases, tubers of one and the same Harbinger potato plant developed plants of which some were infected by the slight type and some by the severe type of the virus disease. Consequently, somatic mutations (cf. 6) can hardly have been the reason for the appearance of the different types of the disease. Thus the fact that none of the different types of the virus disease observed in the variety Harbinger changed to any other type of virus disease in the following vegetative generations of the potato, may indicate that different viruses occasioned the 
disease, and each virus type caused premunity, which prevented a new infection of the plant, i.e., the different types of symptom occurring in the variety $\mathrm{H}$ arbinger were probably caused by different races of the same virus species.

In the potato varieties Aquila and King George $\mathrm{V}$, only the severe type of the disease was observed. Moreover, in these potato varieties the primary symptoms (leaflets a little wrinkled, and small dark brown necrotic streaks on the underside of the leaflet) appeared to be clearly different from those displayed in the variety Harbinger, in which uniform areas of the leaflets turned brown. However, it is known (cf. 5), that one and the same virus species causes different kinds of symptoms in different potato varieties. Futher to this, in all these potato varieties the secondary symptoms of the severe type were almost identical. Again, the potato varieties King George $\mathrm{V}$ and Aquila became virus-infected only after cultivation in the immediate vicinity of the virus-diseased Harbinger potato plants. Consequently, it is presumed that the virus diseases which appeared in all the three potato varieties were caused by one and the same virus species.

Antiserum against potato virus $\mathrm{Y}$ gave a positive reaction. It is true that this result cannot be considered conclusive, as the normal serum used also reacted positively with the sap of the plants. On the base of the symptoms, the virus disease concerned seems to be the potato rugose, caused by potato virus Y [Solanum virus 2 (Orton) Smith]. It is known (cf. 8) that many races which cause different kinds of symptom in one and the same potato variety belong to this virus species.

Virus S was present in many plants of the potato varieties studied. However, no correlation was observed between the appearance of this virus species and the symptoms occurring in the potato plants. The effect of the potato virus $\mathrm{S}$ on the potato plant is also generally very slight, or the infection could be of a quite latent nature $(1,7)$.

\section{Conclusions}

The virus disease occurring in the potato varieties Harbinger, Aquila, and King George $\mathrm{V}$ was probably the potato rugose caused by potato virus Y (Solanum virus 2).

In the variety Harbinger, the degree of strength of the virus disease probably varied as a result of the appearance of different races of potato virus Y. The type of the virus disease did not change from one vegetative generation of the potato to another. In the potato varieties Aquila and King George V, only the severe type of the disease was observed.

The severe type of the virus disease reduced the tuber yield of all the potato varieties investigated to a level of 5 to $6 \%$, and the slight type occurring in the variety Harbinger to an average of $27 \%$ of the normal. The virus infection appeared more frequently in Harbinger than in the variety Aquila. 
In the summer, when the infection of the potato plant took place, the virus disease reduced its productivity only relatively little. In the following vegetative generation of the diseased potato plants, the degree of their degeneration conclusively displayed itself. Following this, the wakening of the virus diseased plants did not progress further from one vegetative generation to the next.

\section{R E F E R N C E S}

(1) AUra, KLAUs 1957. Suomessa viljellyn perunan virustaudeista (On potato virus diseases in Finland) Maatal. tiet. aikak. 29: 103-110.

(2) BrUmmer, VeIKкo 1946. Tutkimuksia tärkeimmistä Tammistossa esiintyneistä perunavirooseista. Hankkijan siemenjulk. 1946: $176-185$.

(3) - - 1949. Vesijärven ja Tammiston aikaisen suhtautumisesta perunavirooseihin (On susceptibility to the virus diseases of Harbinger and Tammisto Early potatoes). Maatal. tiet. aikak. 21 : $17-28$.

(4) Jamalainen, E. A. 1946. The significance of potato virus diseases in Finland. Ibid. 18: 134-146.

(5) Klinkowski, Maximilian 1958. Pflanzliche Virologie II. Berlin.

(6) Pohjakallio, Onni \& Karhuvaara, Laura 1960. Resistance to virus diseases of some $F_{1}$-clones descended from the species hybridization Solanum demissum x S. tuberosum. Maatal. tiet. aikak. 32: $73-80$.

(7) Rønde Kristensen, H. 1956. Kartoffel Virus S. Ugeskr. for lantm. 101: $323-326$.

(8) Smith, Kenneth 1957. A Textbook of Plant Virus Diseases. Boston.

SELOST US:

\section{VIIRUVIROOSIN VAIKUTUKSESTA PERUNAN SADON MÄÄRÄÄN}

Onni Pohjakallio, Laura Karhuvaara ja Simo Antila

Yliopiston kasvipatologian laitos, Helsinki

Helsingin yliopiston Viikin koetilalla suoritetuissa kokeissa esiintyi Vesijärvi-, Aquila- ja Kuningas Yrjö V-perunoissa runsaasti virustautia, joka todennäköisesti oli viiruviroosia. Vesijärvi-perunassa taudin ankaruus suuresti vaihteli. Vaihtelu nähtävästi johtui viiruviroosin aiheuttajan (perunan Y-virus 1, Solanum virus 2 ) erilaisten patogeenisten rotujen esiintymisestä. Taudin ankaruustyyppi ei sairaan kasvin kasvullisesta sukupolvesta toiseen kertaakaan muuttunut. Aquila- samoin kuin Kuningas Yrjö Vperunassa esiintyi vain taudin ankaraa tyyppiä; se heikensi tutkittujen perunalajikkeiden satoisuuden 5-6 prosenttiin normaalisesta. Vesijärvi-perunassa esiintyi myös virustaudin lievää muotoa, joka aiheutti satoisuuden alenemisen keskimäärin n. 27 prosenttiin terveen perunan satoisuudesta. Virustautitartunnan sai Vesijärvi-peruna paljon herkemmin kuin Aquila. Perunan satoisuuden heikentyminen oli saastumiskesänä vain osittaista, mutta sairaan kasvin jo ensimmäisissă kasvullisissa jälkeläiskasveissa se ilmeni lopullisena. Seuraavissa kasvullisissa sukupolvissa ei tauti enää aiheuttanut perunan lisääntyvää surkastumista. 